\title{
DETERMINANT OF MICROCREDIT REPAYMENT
}

\author{
Farida $^{7}$ \\ Hermanto Siregar \\ Nunung Nuryartono \\ Eka Intan $K P$
}

\begin{abstract}
This paper investigate the determinants of microcredit repayment by employing the logistic regression on micro-business households in Pati, Central Java. The result of this study reveals that loan repayment affected significantly by the business lines, food consumption spending, side job, other loan sources, collateral, and credit constrained. Interestingly, the result concludes that the loan repayment are no longer influenced by moral hazard, since the characteristics such as gender, education level, age, experience do not significantly encourage borrowers to repay. This paper also conform the important role of peer-screening process on hindering the credit default.
\end{abstract}

Keywords: micro-credit, repayment, credit constrained, moral hazard

JEL Classification: C13, G21

1 Farida (corresponding author; farida.muchson@gmail.com) is a lecturer at Economic Department, UPI YAI Jakarta. Hermanto Siregar (hermansiregar@yahoo.com) is a professor at Department of Economic, Institut Pertanian Bogor; Nunung Nuryartono (nuryartono@ yahoo.com) and Eka Intan KP (eputri_2@yahoo.com) are lecturers at Department of Economic, Institut Pertanian Bogor. 


\section{PENDAHULUAN}

Masalah utama skim kredit di Indonesia selama ini adalah kredit macet. Program Bimbingan masal (Bimas), Intensifikasi masal (Inmas), Intensifikasi khusus (Insus), dan Kredit Usaha Tani (KUT) mengalami tunggakan sehingga konsekuensinya program tidak berlanjut. Skim selanjutnya adalah kredit ketahanan pangan (KKP), namun penyalurannya pun belum optimal. Perbedaan KUT dan KKP adalah sumber pendanaan dan tanggung jawab resikonya (Supadi dan Sumedi, 2004). Sumber pendanaan KUT dari kredit likuiditas Bank Indonesia (KLBI) dan resiko ditanggung pemerintah. Pendanaan KKP oleh bank pelaksana dan resiko ditanggung 50 persen oleh bank pelaksana. Total jumlah tunggakan KUT mencapai Rp 5,7 trilyun atau 81,4 persen (voice of Indonesia, 2012). Kegagalan KUT ini karena 1) penyalurannya salah sasaran, 2) lembaga-lembaga penyalur fungsinya hanya sebatas penyaluran dana, setelah menyalurkan lembaga tersebut sulit untuk dilacak. Kegagalan ini menimbulkan pertanyaan, bagaimana proses screening awal dalam penyaluran kredit. Peer-screening yang ketat memiliki dampak untuk mengurangi resiko gagal bayar. Namun tidak dipungkiri bahwa screening awal terkendala oleh informasi asimetrik yang berarti tidak semua informasi peminjam teramati ( Ofonyelu, et al., 2013).

Belajar dari pengalaman sebelumnya, dengan perbaikan persyaratan, tingkat suku bunga yang terjangkau, dan resiko kredit, maka kemudian digulirkan program kredit usaha rakyat (KUR) untuk mengganti program-program sebelumnya. Penyaluran KUR terlihat mengalami keberhasilan dilihat dari peningkatan yang cukup signifikan. KUR merupakan kredit modal kerja atau investasi untuk usaha yang feasable namun belum bankable. Dana yang disalurkan adalah milik bank-bank pelaksana yang ditunjuk pemerintah. Pemerintah berperan sebagai penyedia jaminan. Sinergi antara subsidi pemerintah dengan bank komersial diharapkan mampu meningkatkan kredit yang disalurkan dan tidak mengalami resiko gagal bayar. Jumlah KUR yang disalurkan untuk usaha mikro di Indonesia sejak digulirkan tahun 2007 sampai Oktober 2014 meningkat luar biasa dari Rp 17,19 trilyun menjadi Rp 171,67 trilyun. Rata-rata tingkat non performance loan (NPL) tahun 2014 sekitar 3,2 persen lebih kecil dari yang disyaratkan oleh Bank Indonesia. Kredit formal lebih terorganisir dengan staf yang kualitas dan motivasi yang tinggi dibandingkan dengan yang informal (Onyeagocha, 2012). Meskipun tingkat NPL rendah, namun pasar kredit tetap memiliki resiko yang melekat seperti pembayaran yang tidak lancar atau mengalami keterlambatan. Sehingga aspek manajemen risiko pembiayaan mikro tidak boleh diabaikan (Setargie, 2013).

KUR disalurkan untuk tujuan pengurangan kemiskinan, termasuk pemberdayaan perempuan. Namun, tampaknya total jumlah wanita yang memiliki akses KUR dalam penelitian ini hanya sekitar 21,93 persen. Padahal resiko moral hazard wanita lebih rendah dibandingkan dengan pria (D'espallier, et al., 2011) harusnya wanita mendapat prioritas untuk mendapatkan kredit. Penelitian (Armendariz dan Morduch, 2005; Chakravarty, et al., 2013) menemukan bahwa peminjam wanita menunjukkan pembayaran kembali yang lebih bagus baik di dua komunitas yaitu masyarakat patriliniel maupun matriliniel. Namun studi empiris ini biasanya 
untuk pinjaman informal, dimana wanita sebagai nasabah dominan. Menurut the microcredit summit campaign lebih dari 70 persen nasabah keuangan informal adalah wanita. Menurut Okojie, et al. (2010) memperkirakan bahwa 84,2 persen nasabah termiskin keuangan mikro adalah wanita. Kenyataannya banyak pinjaman informal dengan pelanggan wanita yang mengalami gagal bayar juga. Penelitian Godquin (2004) tidak membuktikan bahwa peminjam wanita memiliki pembayaran kembali yang lebih baik. Koefisien hasilnya positif namun tidak signifikan. Kredit usaha rakyat mikro ditujukan kepada usaha mikro dari berbagai sektor, namun data di Gambar 1 menunjukkan yang terbanyak adalah usaha dagang atau ritel. Sektor pertanian tampaknya masih kurang mendapatkan perhatian dilihat dari jatah kredit pertanian yang kecil. Pertanian dianggap sektor yang memiliki tingkat default risk yang tinggi. Dalam penelitian Gebeyehu (2013), para petani mengalami gagal bayar karena alasan faktor-faktor sosial, ekonomi dan kelembagaan.

KUR disalurkan untuk membiayai modal kerja usaha dan atau investasi, sehingga diharapkan usaha mikro mampu berkembang. Namun, bank-bank belum mampu mengontrol sejauh mana pinjaman itu digunakan untuk kepentingan produktif. Apakah untuk modal usaha atau keperluan lain, seperti konsumsi, biaya keluarga sakit atau biaya anak sekolah. Ketika pengalihan kredit dilakukan maka usaha mikro akan mengalami kesulitan dalam pembayaran. Pengalihan kredit termasuk moral hazard yang dilakukan nasabah dari keperluan yang produktif ke kepentingan yang tidak produktif.

Dalam penelitian ini, kita akan melihat sektor ekonomi apakah yang lancar maupun tidak dalam pembayaran KURnya. Faktor-faktor determinan apa yang signifikan mempengaruhi pengembalian KUR. Kemudian, bagaimana peran gender dalam pengembalian kredit formal, apakah resiko moral hazard masih relevan diharapkan juga dalam penelitian ini?

Bagian selanjutnya dari paper ini mengulas teori dan studi empiris yang terkait dengan tingkat pengembalian pinjaman. Bagian ketiga mengulas data dan regresi logistik yang digunakan dalam paper ini. Bagian keempat mengulas hasil estimasi dan analisinya, sementara kesimpulan disajikan pada bagian kelima dan menjadi bagian penutup.

\section{TEORI}

Pinjaman KUT, KKP, program nasional pemberdayaan masyarakat (PNPM) berbasis kelompok yang berfungsi sebagai peer-screening, peer-monitoring sekaligus peer-enforcement. Sementara KUR merupakan model pinjaman berbasis individu yang dilakukan oleh bank komersil yang membutuhkan standar persyaratan yang diterapkan lebih obyektif. Prospek bisnis, kelayakan dan jaminan menjadikan nilai tambah dalam menentukan pinjaman yang akan diberikan. KUR ditujukan untuk peminjam individu bukan model pinjaman yang berbasis kelompok.

Lukman dkk (2008) dalam kajian upaya penguatan peran microbanking melalui group approach di Sumatra Barat menyimpulkan bahwa keberhasilan pendekatan pembiayaan 
berkelompok ini sangat ditentukan oleh karakteristik sosial budaya masyarakat dimana lembaga pembiayaan mikro berada, sehingga tingkat kesuksesan juga beragam yang berdampak terhadap sikap dan perilaku dalam mengelola kredit. Adanya komitmen kelompok yang tinggi yang berasal dari suatu etnis tertentu, menyebabkan tingkat kepatuhan anggota yang cukup tinggi terhadap ketua kelompok selaku pemberi rekomendasi. Tanggung jawab yang dipikul oleh nasabah kelompok ini bersifat tanggung renteng, sehingga fungsi kontrol sosial sangat menentukan motivasi dan komitmen anggota dalam pelunasan kredit. Biasanya jaminan terhadap kesuksesan pelunasan kredit diatur oleh ketua dalam bentuk joint liability atau social collateral.

Jaringan komunikasi yang berkembang saat ini tampaknya bisa mengurangi hambatan dari sisi biaya transaksi yang tinggi dari bank bank formal untuk melakukan penagihan. Biaya komunikasi yang murah dirasa lebih efektif daripada petugas datang langsung ke nasabah. Faktor faktor lain yang diperkirakan mempegaruhi keberhasilan pengembalian kredit adalah perilaku pelaku usaha rumah tangga itu sendiri seperti gender, pendidikan, penyalahgunaan fungsi kredit, pengalaman dalam menggunakan kredit maupun konsumsi rumah tangga. Karakteristik perilaku tersebut bisa dimasukkan sebagai faktor internal dari pelaku usaha mikro atau perilaku peminjam. Setargie (2013) memasukkan faktor kinerja usaha yang buruk yang mempengaruhi keterlambatan pembayaran. Pengalihan kredit untuk penggunakan yang tidak menguntungkan, jumlah tanggungan dan masalah kepemilikan merupakan faktor-faktor lain yang menyebabkan gagal bayar. Sebaliknya pendidikan, pendapatan, pengawasan, periode pembayaran yang sesuai dan ketersediaan sumber kredit lain merupakan faktor penting dan signifikan mempengaruhi kelancaran pembayaran kembali kredit.

Jalaludin (2002) mengidentifikasikan faktor faktor yang mempengaruhi kelancaran pengembalian kredit pengusaha kecil adalah faktor ekonomi dan faktor non ekonomi. Faktor ekonomi meliputi; 1) penghasilan bersih yang diterima oleh pengusaha kecil baik dari usaha taninya maupun dari kegiatan di luar pertanian. 2) jumlah tanggungan keluarga. Semakin besar jumlah anggota keluarga berarti semakin besar tanggung jawab rumah tangga dan semakin mengurangi kemampuan untuk membayar kembali pinjaman. 3) Skala usaha, yaitu diukur berdasarkan besarnya modal yang diperlukan untuk menjalankan usaha. 4) frekwensi dan besarnya angsuran. Sedangkan faktor faktor non ekonomi adalah tingkat pendidikan, frekwensi pembinaan, dan bidang usaha. Roslan dan Karim (2009) mengidentifikasi faktorfaktor karakteristik peminjam, karakteristik perusahaan, dan karakteristik pinjaman, sedangkan Nawai dan Shariff (2013) menambahkah karakteristik lembaga keuangan.

\section{METODOLOGI}

Survey lapangan dilakukan untuk memperoleh informasi spesifik terkait data-data tentang pelaku usaha mikro, pendapatan, dan indikator kesejahteraan yang akan digunakan untuk melengkapi data sekunder. Data primer dikumpulkan melalui kuesioner dan wawancara dengan menggunakan daftar kuesioner dan pertanyaan terstruktur terhadap pelaku usaha 
mikro. Penentuan lokasi berdasarkan sampling bertahap (multistage sampling purposive). Tahap pertama, pemilihan provinsi yaitu, Jawa Tengah sebagai penerima kredit usaha rakyat terbesar atau sekitar 15,12 persen dari total plafond KUR tahun 2012. Kedua, pemilihan lokasi kabupaten yaitu berdasarkan penyalur KUR terbesar dan terpilih Kabupaten Pati. Tahap selanjutnya adalah pemilihan kecamatan berdasarkan jarak lokasi kecamatan dengan akses pasar kota diambil kecamatan yang terdekat dan kecamatan yang terjauh dari kecamatan kabupaten kota. Jarak atau lokasi dianggap akan mempengaruhi akses pasar, perbankan, dan informasi yang akan menentukan keberhasilan suatu usaha. Kecamatan yang terpilih adalah Kecamatan Margorejo sebagai kecamatan terdekat dengan jarak 4 kilometer dan Kecamatan Dukuhseti dengan jarak 36 kilometer.

Jumlah sampel yang diambil berdasarkan rumus Slovin ${ }^{2}$ adalah sebagai berikut; $n=N /(1$ $\left.+\mathrm{N}(\mathrm{e})^{2}\right)$, dimana $\mathrm{N}$ adalah populasi atau total nasabah KUR yang ada di Kabupaten Pati yaitu 25.080 orang dan dengan tingkat kesalahan pengambilan sampel yang masih dapat ditolerir/ diinginkan sebesar 8 persen maka diperoleh sampel sebesar 155 rumah tangga usaha mikro yang mendapatkan KUR. Berdasarkan proporsi besarnya KUR yang disalurkan dan banyaknya jumlah desa antar Kecamatan Dukuhseti dan Kecamatan Margorejo, maka sampel di Kecamatan Dukuhseti (86 unit rumah tangga usaha mikro) dan Kecamatan Margorejo sebanyak (69 unit).

Penelitian dalam paper ini menggunakan regresi logistik untuk menentukan faktor-faktor determinan yang mempengaruhi usaha mikro membayar KUR. Penelitian lain menggunakan pendekatan serupa dilakukan oleh Tundui dan Tundui (2013), dan Mokhtar, dkk., (2012). Varian model yang masih tergolong dalam model discrete choice seperti model probit juga dilakukan oleh Godquin (2004), Vitor (2012), Setargie (2013), Wongnaa dan Vitor (2013), dan juga Gebeyehu, et al. (2013). Variabel dependen pada regresi logistik ini merupakan variabel respon yang terkategori dua atau lebih, sementara variabel penjelasnya dapat berbentuk kategorik ataupun kontinyu.

Spesifikasi model logistik untuk suatu peluang kejadian $P(Y=1 \mid x)$ dengan serangkaian variabel penjelas $X_{i}$ adalah sebagai berikut:

$$
\mathrm{g}\left(\mathrm{x}_{\mathrm{i}}\right)=\operatorname{In} \frac{P(Y=1 \mid \mathrm{x})}{1-P(Y=1 \mid \mathrm{x})}=\beta_{1}+\beta_{2} X_{2 i}+\ldots+\beta_{k} X_{k i}
$$

dan model regresi logistik gandanya:

$$
\mathrm{P}\left(\mathrm{x}_{\mathrm{i}}\right)=\frac{1}{1+e^{-g(\mathrm{xi})}}=\frac{e^{g(x i)}}{1+e^{g(x i)}}
$$

2 Lihat antara lain Umar (2004). 
Secara umum jika sebuah peubah berskala nominal atau ordinal mempunyai $k$ kemungkinan nilai, maka diperlukan k-1 peubah boneka (dummy variable), sehingga model transformasi logitnya menjadi:

$$
g\left(x_{i}\right)=\beta_{1}+\beta_{2} x_{2 i}+\ldots+\Sigma_{u=1}^{k j-1} \beta_{j u} D_{j u}+\beta_{k} X_{k}
$$

dimana:

$$
\begin{array}{ll}
\mathrm{u} & : 1,2,3 \ldots, \mathrm{k}_{\mathrm{j}-1} \\
\mathrm{D}_{\mathrm{ju}} & : \mathrm{k}_{\mathrm{j}-1} \text { peubah boneka } \\
\beta_{\mathrm{ju}} & : \text { koefisien peubah boneka } \\
\mathrm{X}_{\mathrm{j}} & : \text { peubah bebas ke-j dengan tingkatan } \mathrm{k}_{\mathrm{j}}
\end{array}
$$

Pendugaan parameter dalam regresi logistik menggunakan pendekatan maximum likehood. Jika peluang suatu kejadian diasumsikan bebas dengan kejadian lain, maka fungsi probabilitasnya adalah:

$$
\ell(\beta)=\sum\left(\mathrm{x}_{1}\right) \sum\left(\mathrm{x}_{2}\right) \ldots \sum\left(\mathrm{x}_{\mathrm{n}}\right)=\prod_{i=1}^{n} \sum(\mathrm{xi})
$$

Prinsip prosedur MLE adalah menentukan dugaan $\beta$ yang nilainya akan memaksimumkan joint probability atau peluang bersama $n$ pengamatan. Untuk memudahkan perhitungan dilakukan transformasi dengan logaritma natural, sehingga mendapatkan fungsi log likehood berikut;

$$
\ell(\beta)=\operatorname{In} \ell(\beta)=\sum_{i=1}^{n}\left\{y_{i} \operatorname{In}\left[P\left(x_{i}\right)\right]+\left(1-y_{i}\right) \operatorname{In}\left[1-P\left(x_{i}\right)\right]\right\}
$$

Dengan syarat turunan pertama terhadap $\alpha$ dan $\beta$ kita dapat memperoleh penduga $\beta$ yang memaksimumkan $\ell(\beta)$ tersebut.

Pengujian model secara keseluruhan dapat dilakukan dengan uji likehood ratio, P, yang tersebar mengikuti bentuk distribusi Khi-kuadrat dengan derajat bebas $(k-1)$ berikut:

$$
\mathrm{P}=-2 \mathrm{In}\left[\frac{\text { likehood }_{\text {Model }_{R}}}{\text { likehood }_{\text {Model }_{U R}}}\right]=2 \mathrm{In}\left[\frac{\text { likehood_Model }_{R}}{\text { likehood_Model }_{U R}}\right] \approx \chi_{(k-1)}^{2}
$$

Dimana Model $_{\mathrm{UR}}$ merupakan model unrestricted atau model lengkap dengan $\beta_{j} \neq 0$. Pada sisi lain, pengujian pengaruh individual masing-masing variabel penjelas dapat dilakukan dengan uji Wald dengan statistik $W$ berikut: 


$$
\mathrm{W}=\frac{\widehat{\beta}}{s e(\beta \mathrm{j})}
$$

Statistik W ini tersebar mengikuti bentuk distribusi normal.

Interprestasi koefisien untuk model regresi logistik biner dapat dilakukan dengan menggunakan nilai kecenderungan atau odd ratio. Odds ratio bisa didefinisikan sebagai berapa kali kemungkinan pilihan-1 diantara individu dengan $\mathrm{x}=1$ dibandingkan diantara individu dengan $\mathrm{x}=0$ (lihat antara lain Juanda (2009)). Rasio odds diformulasikan sebagai berikut:

$$
\Psi=\frac{e^{\alpha+\beta} /\left(1+e^{\alpha+\beta}\right)}{1 /\left(1+e^{\alpha+\beta}\right)} / \frac{e^{\alpha} /\left(1+e^{\alpha}\right)}{1 /\left(1+e^{\alpha}\right)}=e^{\beta}
$$

Sejalan dengan penelitian Roslan dan Karim (2009), serangkaian variabel penjelas yang digunakan mencakup karakteristik peminjam, karakteristik usaha mereka, dan karakteristik

\begin{tabular}{|c|c|c|}
\hline \multicolumn{3}{|c|}{$\begin{array}{c}\text { Tabel } 1 . \\
\text { Deskripsi variabel-variabel dalam model logit }\end{array}$} \\
\hline Nama Variabel & Tipe Variabel & Penjelasan \\
\hline$p(x i)$ & Biner & Pembayaran KUR ( $1=$ lancar, $0=$ terlambat $)$ \\
\hline \multicolumn{3}{|l|}{ Karakteristik peminjam; } \\
\hline Kecamatan (X1) & Biner & Lokasi penelitian $(1=$ Kec. Dukuhseti, $0=$ Kec. Margorejo) \\
\hline Gender (X2) & Biner & Gender pemilik usaha mikro ( $1=$ laki-laki, $0=$ perempuan $)$ \\
\hline Usia (X3) & Kontinyu & Usia pemilik usaha mikro \\
\hline \multicolumn{3}{|l|}{ Tingkat pendidikan (X4) } \\
\hline Pendidikan_1 & Biner & $1=\mathrm{SD}, 0$ lainnya \\
\hline Pendidikan_2 & Biner & 2 = SMP, 0 lainnya \\
\hline Pendidikan_3 & Biner & $3=$ SMA, 0 lainnya \\
\hline Pengeluaran makanan (X5) & Kontinyu & Jumlah pengeluaran RT untuk makanan/bulan \\
\hline Pekerjaan sampingan (X6) & Biner & $1=$ memiliki pekerjaan sampingan, 0 tidak \\
\hline Pasangan bekerja (X6) & Biner & 1 = Suami/istri bekerja, 0 tidak \\
\hline Jumlah tanggungan $(X 7)$ & Kontinyu & Jumlah anak yang masih ditanggung \\
\hline \multicolumn{3}{|l|}{ Karakteristik usaha; } \\
\hline Jarak ke bank (X8) & Kontinyu & Lokasi usaha ke bank (km) \\
\hline \multicolumn{3}{|l|}{ Jenis usaha (X9) } \\
\hline Jenis usaha_1 & Biner & 1 = dagang dan ritel, 0 lainnya \\
\hline Jenis usaha_2 & Biner & 2 = jasa, 0 lainnya \\
\hline Jenis usaha_3 & Biner & $3=$ pengolahan, 0 lainnya \\
\hline Lama usaha (X10) & Kontinyu & Berapa lama usaha berdiri (tahun) \\
\hline
\end{tabular}
produk pinjaman seperti ditampilkan pada Tabel 1. 


\begin{tabular}{|c|c|c|}
\hline Nama Variabel & Tipe Variabel & Penjelasan \\
\hline Hambatan usaha (X11) & Biner & $\begin{array}{l}\text { Hambatan yang dihadapi oleh usaha mikro ( } 1=\text { modal, } \\
0 \text { marketing) }\end{array}$ \\
\hline Penjualan (X12) & Kontinyu & Penjualan per minggu (Rp) \\
\hline Modal kerja (X13) & Kontinyu & Modal kerja per minggu (Rp) \\
\hline Pengalihan kredit (X14) & Biner & Pengalihan penggunaan kredit, $1=y a, 0$ tidak \\
\hline Sumber pinjaman lain (X15) & Biner & Sumber pinjaman lain, $1=$ ya, 0 hanya KUR \\
\hline \multicolumn{3}{|l|}{ Karakteristik pinjaman; } \\
\hline \multicolumn{3}{|l|}{ Jaminan (X16) } \\
\hline Jaminan_1 & Biner & 1 = tidak ada jaminan, 0 lainnya \\
\hline Jaminan_2 & Biner & 2 = BPKB motor, 0 lainnya \\
\hline Kredit tidak dibatasi (X17) & Biner & $\begin{array}{l}\text { Apakah pinjaman disetujui sesuai dengan yang diminta } \\
\text { (credit constrained), 1= disetujui semua, } 0 \text { lainnya }\end{array}$ \\
\hline Periode angsuran (X18) & Kontinyu & Lamanya angsuran (bulan) \\
\hline
\end{tabular}

\section{HASIL DAN ANALISIS}

KUR ini merupakan pinjaman formal yang memiliki ciri yang berbeda dengan jenis pinjaman lain. KUR pertama kali dicanangkan tahun 2007. Awalnya KUR disalurkan melalui 7 bank pelaksana, yaitu Bank Nasional Indonesia (BNI), Bank Mandiri, Bank Rakyat Indonesia (BRI), Bank Tabungan Nasional (BTN), Bukopin, Syariah Mandiri, dan BNI Syariah. Untuk mempercepat penyaluran, bank-bank pelaksana ditambah melalui 26 Bank Pembangunan Daerah (BPD) di masing-masing wilayah. Sampai Oktober 2014, Berdasarkan data dari Komite-KUR, total jumlah nasabah 11,92 juta. Rata-rata kredit yang diterima oleh setiap nasabah sebesar Rp 13,1 juta. Sektor perdagangan tampaknya mendominasi penyaluran KUR sebesar Rp 97,2 trilyun atau 56,62 persen. Sektor kedua pertanian menyerap Rp 30,1 trilyun atau 17,53 persen. Sisanya disalurkan di sektor-sektor lain seperti di Gambar 1 berikut.

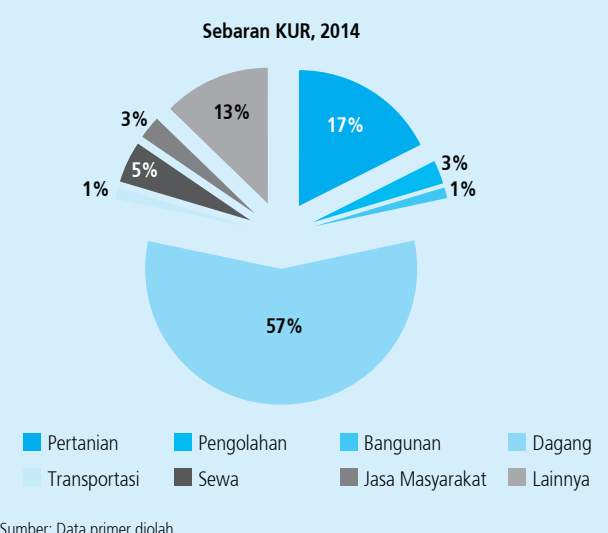

Sumber: Data primer diolah

Gambar 1. Sebaran KUR menurut sektor usaha 
Secara keseluruhan, nilai Non Performance Loan (NPL) penyaluran KUR oleh bank pelaksana ini masih dibawah 5\% yaitu sebesar 3,2\% (Nopember 2014). Diharapkan pada periode-periode berikutnya nilai NPL pada bank yang masih di atas $5 \%$ bisa turun sehingga penyalurannya lebih tepat sasaran. Karakteristik skema KUR secara umum ditampilkan dalam Tabel 2 berikut;

\begin{tabular}{|c|c|c|}
\hline \multicolumn{3}{|r|}{$\begin{array}{c}\text { Tabel } 2 . \\
\text { Karakteristik umum skema KUR }\end{array}$} \\
\hline No. & Deskripsi & Penjelasan \\
\hline 1. & Tujuan & $\begin{array}{l}\text { Menyediakan modal kerja dan investasi ke usaha mikro yang layak tapi } \\
\text { belum bankable }\end{array}$ \\
\hline 2. & Maks. pinjaman & Rp $20,000,000$ \\
\hline 3. & Tingkat bunga & Maks. $22 \%$ per tahun \\
\hline 4. & Lama periode & 3 tahun untuk modal kerja, 5 tahun untuk investasi \\
\hline 5. & Penjamin & $\begin{array}{l}\text { Pemerintah; } 80 \% \text { untuk pertanian, laut dan perikanan, usaha mikro dan } 70 \% \text { untuk } \\
\text { sektor lainnya }\end{array}$ \\
\hline 6. & Perusahaan asuransi & PT Jamkrindo, PT Askrindo, PT Jamkrida Jatim, PT Jamkrida Bali Mandara \\
\hline 7. & Sumber dana & $100 \%$ oleh bank pelaksana \\
\hline 8. & Usaha mikro & $\begin{array}{l}\text { Maks. Aset bersih <= Rp } 50 \text { juta diluar tanah dan tempat usaha, atau maks. } \\
\text { penjualan Rp } 300 \text { juta per tahun, atau tenaga kerja kurang dari } 5 \text { orang }\end{array}$ \\
\hline
\end{tabular}

\subsection{Karakteristik Kreditur}

Dalam penelitian ini, variabel dependen merupakan biner antara rumah tangga usaha mikro yang pembayaran kembali pinjaman KUR baik atau lancar, dengan rumah tangga usaha mikro yang mengalami kesulitan dalam pembayaran kredit atau terlambat. Pembayaran baik atau lancar berarti tidak pernah mengalami keterlambatan atau tidak lebih dari dua kali selama masa pelunasan. Pembayaran yang dikategorikan terlambat jika sering mengalami keterlambatan atau lebih dari dua kali. Ini merujuk pada variabel dependent dalam penelitian (Mokhtar et al., 2012) yang mengelompokkan pembayaran yang buruk jika keterlambatan lebih dari 4 kali. Total jumlah responden sebanyak 155 usaha mikro, yang pembayaran pinjaman KUR lancar sebanyak 134 unit atau 86,45 persen dan sisanya sebanyak 21 unit atau 13,55 persen rumah tangga usaha mikro yang mengalami kesulitan. Perempuan memiliki tingkat keterlambatan sebanyak 14,29 persen. Karakteristik peminjam usaha mikro berada di Tabel 3. 


\begin{tabular}{|c|c|c|c|c|c|c|}
\hline \multicolumn{7}{|c|}{$\begin{array}{l}\text { Tabel } 3 . \\
\text { Karakteristik Demografi }\end{array}$} \\
\hline \multirow{2}{*}{ Deskripsi } & \multicolumn{2}{|c|}{$\begin{array}{l}\text { Pembayaran terlambat } \\
\qquad\left(\mathrm{N}_{1}=21\right)\end{array}$} & \multicolumn{2}{|c|}{$\begin{array}{l}\text { Pembayaran lancar } \\
\qquad\left(\mathrm{N}_{2}=134\right)\end{array}$} & \multicolumn{2}{|c|}{$\begin{array}{l}\text { Total responden } \\
\qquad\left(N_{3}=155\right)\end{array}$} \\
\hline & $\begin{array}{c}\text { Jumlah } \\
\left(\mathrm{n}_{1}\right)\end{array}$ & $\%$ dari $\mathrm{N}_{1}$ & $\underset{\left(n_{2}\right)}{\text { Jumlah }}$ & $\%$ dari $\mathrm{N}_{2}$ & $\begin{array}{l}\text { Sub-Total } \\
\left(N_{4}=n_{1}+n_{2}\right)\end{array}$ & $\% \mathrm{~N}_{3}$ \\
\hline \multicolumn{7}{|l|}{ Demografi; } \\
\hline \multicolumn{7}{|l|}{ Gender } \\
\hline Laki-laki & 18 & 85,71 & 103 & 76,87 & 121 & 78,07 \\
\hline Perempuan & 3 & 14,29 & 31 & 23,13 & 34 & 21,93 \\
\hline \multicolumn{7}{|l|}{ Usia } \\
\hline $23-37$ th & 4 & 19,05 & 64 & 47,76 & 68 & 43,87 \\
\hline $38-52$ th & 15 & 71,43 & 60 & 44,78 & 75 & 48,39 \\
\hline $53-67$ th & 2 & 9,52 & 10 & 7,46 & 12 & 7,74 \\
\hline \multicolumn{7}{|l|}{ Pendidikan } \\
\hline SD & 8 & 38,10 & 38 & 28,36 & 46 & 29,68 \\
\hline SMP & 8 & 38,10 & 38 & 28,36 & 46 & 29,68 \\
\hline SMA & 4 & 19,04 & 54 & 40,30 & 58 & 37,42 \\
\hline D3 atau S1 & 1 & 4,76 & 4 & 2,98 & 5 & 3,22 \\
\hline
\end{tabular}

Usia dikelompokkan menjadi 3, proporsi terbanyak antara usia 38-52 tahun sebanyak 48,39 persen dan antara usia 23-37 tahun sebanyak 43,87 persen. Usia yang mengalami keterlambatan untuk rentang 38-52 tahun proporsinya jauh lebih besar yaitu sekitar 71,43 persen. Pendidikan yang terbanyak dengan proporsi yang sama adalah lulusan sekolah dasar dan sekolah menengah pertama. Lulusan pendidikan tinggi yang menggunakan KUR untuk usahanya hanya 5 orang atau 3,22 persen. Dari 5 orang tersebut yang mengalami kesulitan pembayaran 1 orang atau 20 persen yang berarti prosentase kegagalan paling besar dari keseluruhan responden. Karakteristik peminjam berkaitan dengan ekonomi ditampilkan dalam tabel 4 berikut. 


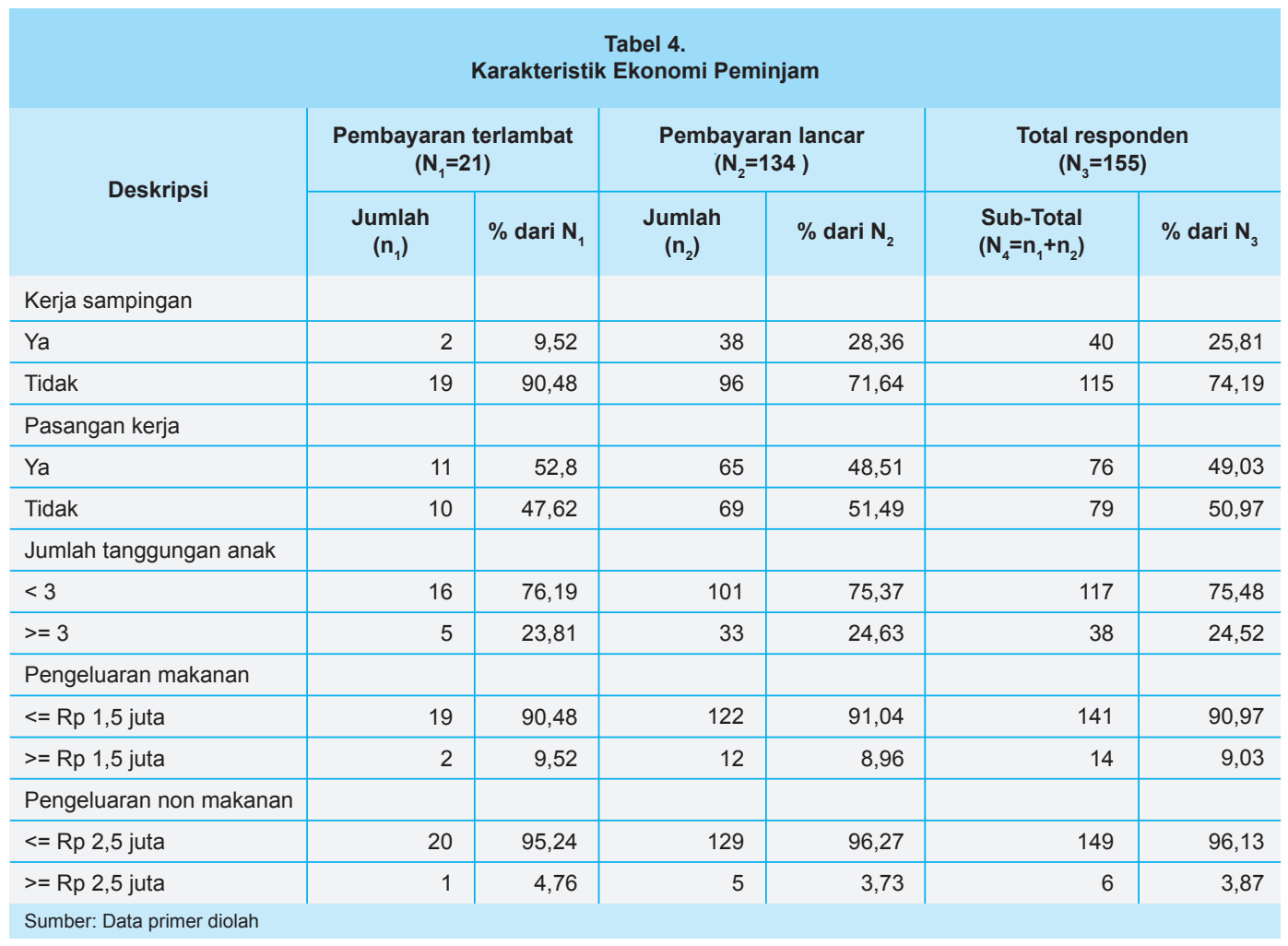

Banyak nasabah KUR yang memiliki kerja sambilan sekitar 25 persen. Sedangkan yang pasangannya bekerja hampir 50 persen. Jumlah tanggungan adalah jumlah anak yang masih bergantung kepada orang tuanya. Dalam penelitian ini, sebagian besar jumlah tanggungan yang dimiliki oleh usaha mikro kurang dari 3 orang yaitu lebih dari 75 persen. ini berarti banyak usaha mikro yang sudah mengikuti progrm keluarga berncana.

Karakteristik usaha dipaparkan di Tabel 5. Jarak adalah seberapa jauh antara lokasi usaha dengan bank. Rata-rata jarak seluruh responden dari tempat usaha ke lokasi sekitar 4 km, namun untuk kelompok yang mengalami kesulitan pembayaran kembali, rata-rata jaraknya sekitar $6 \mathrm{~km}$. Rata-rata lama usaha yang mengalami kesulitan pembayaran adalah 6 tahun, lebih lama dari usaha mikro yang pembayaran pinjaman bagus rata-rata lama usaha 5 tahun. 


\begin{tabular}{|c|c|c|c|c|c|c|}
\hline \multicolumn{7}{|c|}{$\begin{array}{c}\text { Tabel } 5 . \\
\text { Karakteristik Usaha }\end{array}$} \\
\hline \multirow{2}{*}{ Deskripsi } & \multicolumn{2}{|c|}{$\begin{array}{l}\text { Pembayaran terlambat } \\
\qquad\left(\mathrm{N}_{1}=21\right)\end{array}$} & \multicolumn{2}{|c|}{$\begin{array}{l}\text { Pembayaran lancar } \\
\qquad\left(\mathrm{N}_{2}=134\right)\end{array}$} & \multicolumn{2}{|c|}{$\begin{array}{l}\text { Total responden } \\
\qquad\left(N_{3}=155\right)\end{array}$} \\
\hline & $\begin{array}{c}\text { Jumlah } \\
\left(\mathrm{n}_{1}\right)\end{array}$ & $\%$ dari $\mathrm{N}_{1}$ & $\begin{array}{c}\text { Jumlah } \\
\left(\mathrm{n}_{2}\right)\end{array}$ & $\%$ dari $\mathrm{N}_{2}$ & $\begin{array}{l}\text { Sub-Total } \\
\left(N_{4}=n_{1}+n_{2}\right)\end{array}$ & $\%$ dari $\mathrm{N}_{3}$ \\
\hline Rata-rata jarak (km) & 6 & & 4 & & 4 & \\
\hline Rata-rata lama usaha (th) & 6 & & 5 & & 5 & \\
\hline \multicolumn{7}{|l|}{ Jenis usaha; } \\
\hline Ritel/dagang & 4 & 19,05 & 66 & 49,25 & 70 & 45,16 \\
\hline Service/jasa & 3 & 14,29 & 27 & 20,15 & 30 & 19,36 \\
\hline Pengolahan & 6 & 28,57 & 20 & 14,93 & 26 & 16,77 \\
\hline Lainnya & 8 & 38,09 & 21 & 15,67 & 29 & 18,71 \\
\hline \multicolumn{7}{|l|}{ Hambatan usaha; } \\
\hline Modal & 15 & 71,43 & 88 & 65,67 & 103 & 66,45 \\
\hline Pemasaran & 6 & 28,57 & 46 & 34,33 & 52 & 33,55 \\
\hline $\begin{array}{l}\text { Rata-rata penjualan } \\
\text { per minggu }(\mathrm{Rp})\end{array}$ & 5,32 juta & & 4,41 juta & & 4,54 juta & \\
\hline $\begin{array}{l}\text { Rata-rata modal kerja/ } \\
\text { minggu (Rp) }\end{array}$ & 4,57 juta & & 3,61 juta & & 3,74 juta & \\
\hline \multicolumn{7}{|l|}{ Frekwensi KUR } \\
\hline Sekali & 9 & 42,86 & 88 & 65,67 & 97 & 62,58 \\
\hline Lebih sekali & 12 & 57,14 & 46 & 34,33 & 58 & 37,42 \\
\hline \multicolumn{7}{|l|}{ Pengalihan kredit } \\
\hline Ya & 8 & 38,10 & 19 & 14,18 & 27 & 17,42 \\
\hline Tidak & 13 & 61,90 & 115 & 85,82 & 128 & 82,58 \\
\hline \multicolumn{7}{|l|}{ Sumber pinjaman lain } \\
\hline Ya & 12 & 57,14 & 27 & 20,15 & 39 & 25,16 \\
\hline Tidak & 9 & 42,86 & 107 & 79,85 & 116 & 74,84 \\
\hline \multicolumn{7}{|l|}{$\begin{array}{l}\text { Ingin mendapat pinjaman } \\
\text { bank lagi }\end{array}$} \\
\hline Ya & 17 & 80,95 & 75 & 55,97 & 92 & 59,35 \\
\hline Tidak & 4 & 19,05 & 59 & 44,03 & 63 & 40,65 \\
\hline
\end{tabular}

Secara keseluruhan, jenis usaha yang ditekuni oleh peminjam KUR adalah ritel/dagang yang biasanya berjualan kebutuhan sehari-hari, mie dan bakso, warung dan kios-kios baik yang ada di pasar maupun bertempat usaha di rumah. Jenis usaha jasa meliputi bengkel, salon, catering dan jasa lainnya. Untuk jenis usaha yang masuk kategori lainnya adalah pertanian, peternakan, dan perikanan. Jenis usaha tersebut terbanyak yang mengalami kesulitan pembayaran pinjaman kembali. 
Lebih dari 65 persen hambatan usaha yang dihadapi oleh usaha mikro adalah karena masalah modal. Termasuk didalamnya adalah mesin sering rusak, sulitnya bahan baku, maupun gagal panen. Sedangkan masalah pemasaran yang dihadapi meliputi terbatasnya skala ekonomi, atau kemampuan usaha mikro untuk memperluas atau meningkatkan produksi, begitu juga kurangnya pelanggan.

Rata-rata perputaran penjualan usaha mikro setiap minggunya berkisar antara Rp 4,54 juta dan rata-rata modal kerja sebesar Rp 3,74. Dari total penerima KUR usaha mikro, 62,58 persen menerima KUR untuk pertama kalinya. Sisanya sebesar 37,42 persen menerima KUR lebih sekali atau melakukan suplesi. Suplesi tersebut bisa dilakukan, sepanjang sisa pinjaman dan pinjaman baru tidak melebihi Rp 20 juta. Tujuan dari KUR adalah untuk modal kerja atau modal investasi, namun tidak semua peminjam KUR benar-benar digunakan untuk tujuan tersebut. Sekitar 17,42 persen, peminjam KUR mengalihkan kreditnya untuk kepentingan yang tidak menghasilkan keuntungan, seperti membayar uang sekolah, kebutuhan sehari-hari, maupun membayar cicilan motor. Rumah tangga usaha mikro sebagian tidak mengandalkan hanya KUR saja, tetapi sumber pinjaman lain seperti koperasi, program nasional pemberdayaan masyarakat (PNPM), tetangga, keluarga, rentenir dan sebagainya. Tercatat 25,16 persen usaha mikro nasabah KUR memiliki sumber pinjaman lain. Dari pengguna KUR, ditanyakan apakah memiliki keinginan untuk mendapatkan pinjaman lagi dari bank untuk mendukung usahanya, sekitar 59,35 persen atau lebih separuhnya menjawab ingin mendapat pinjaman bank lagi.

Karakteristik pinjaman dalam penelitian ini bisa juga dimaksudkan sebagai karakteristik kelembagaannya, karena karakteristik yang melekat pada faktor-faktor berikut mewakili karakteristik pinjaman sekaligus karakteristik kelembagaannya. Faktor-faktor tersebut dilihat

\begin{tabular}{|c|c|c|c|c|c|c|}
\hline \multicolumn{7}{|c|}{$\begin{array}{c}\text { Tabel } 6 . \\
\text { Karakteristik Pinjaman }\end{array}$} \\
\hline \multirow{2}{*}{ Deskripsi } & \multicolumn{2}{|c|}{$\begin{array}{l}\text { Pembayaran terlambat } \\
\qquad\left(\mathrm{N}_{1}=21\right)\end{array}$} & \multicolumn{2}{|c|}{$\begin{array}{l}\text { Pembayaran lancar } \\
\qquad\left(\mathrm{N}_{2}=134\right)\end{array}$} & \multicolumn{2}{|c|}{$\begin{array}{l}\text { Total responden } \\
\qquad\left(N_{3}=155\right)\end{array}$} \\
\hline & $\underset{\left(n_{1}\right)}{\text { Jumlah }}$ & $\%$ dari $\mathrm{N}_{1}$ & $\begin{array}{l}\text { Jumlah } \\
\qquad\left(\mathrm{n}_{2}\right)\end{array}$ & $\%$ dari $\mathrm{N}_{2}$ & $\begin{array}{l}\text { Sub-Total } \\
\left(N_{4}=n_{1}+n_{2}\right)\end{array}$ & $\%$ dari $\mathrm{N}_{3}$ \\
\hline \multicolumn{7}{|l|}{ Jaminan; } \\
\hline $1=$ tidak ada & 3 & 14,29 & 4 & 2,98 & 7 & 4,5 \\
\hline $2=\mathrm{BPKB}$ motor & 3 & 14,29 & 64 & 47,76 & 67 & 43,23 \\
\hline 3 = lainnya & 15 & 71,43 & 66 & 49,25 & 81 & 52,29 \\
\hline Lama proses (hari) & 13,57 & & 10,85 & & 11,22 & \\
\hline \multicolumn{7}{|l|}{ Jumlah yang disetujui; } \\
\hline Semua & 13 & 61,90 & 121 & 90,30 & 134 & 86,45 \\
\hline Sebagian & 8 & 38,10 & 13 & 9,70 & 21 & 13,55 \\
\hline $\begin{array}{l}\text { Rata-rata lama angsuran } \\
\text { (bulan) }\end{array}$ & 20,76 & & 20,60 & & 20,62 & \\
\hline Sumber: Data primer diolah & & & & & & \\
\hline
\end{tabular}


dari jenis jaminan yang diserahkan ke bank, lama proses pengajuan sampai dinyatakan diterima atau ditolak, apakah pinjaman disetujui semua apa sebagian begitu pula periode atau lama angsuran pinjaman sampai lunas. Karakteristik-karakteristik ini bisa dilihat di Tabel 6.

Karena asimetrik informasi tentang calon nasabah, maka bank mengenakan syarat jaminan yang dimiliki oleh nasabah. Besarnya jaminan akan menentukan besarnya pinjaman yang akan diberikan. KUR mikro merupakan pinjaman tanpa jaminan. Namun kenyataan, bank tetap mensyaratkan jaminan. Meski demikian dari total nasabah KUR, ada sekitar 4,5\% KUR mikro tidak melampirkan jaminan. Sekitar 43,23 persen dikenakan jaminan sepeda motor. Sisanya yang terbanyak 52,29 persen lain-lain seperti BPKB mobil maupun sertifikat. Selama proses pengajuan kredit sekitar 11,22 hari (termasuk weekend) waktu yang dibutuhkan untuk dana tersebut cair. Normatifnya jika persyaratan terpenuhi maka 3 sampai 5 hari kerja maka dana akan cair. Sebagai nasabah maka ada kewajiban untuk membuka rekening di bank tersebut sebagai sarana untuk mencairkan dana. Tidak semua pengajuan kredit tersebut disetujui, ada sekitar 86,45 persen yang semua pengajuan kreditnya disetujui, sisanya 13,55 persen hanya menerima sebagian dari yang diminta. Persetujuan tersebut merupakan bagian dari peerscreening lembaga keuangan kepada calon nasabahnya dengan membatasi kreditnya. Rata-rata lama angsuran adalah 20,6 bulan yang berarti kurang dari dua tahun.

\subsection{Hasil Estimasi Model}

Estimasi faktor-faktor yang menentukan pelunasan pinjaman diusajikan pada Tabel 7. Dengan likehood ratio (LR) 60,35, degree of freedom 24, model regresi logistik ini secara keseluruhan dapat menjelaskan atau memprediksi keputusan rumah tangga usaha mikro untuk membayar kembali pinjaman KUR.

Dengan melihat nilai-p ( $\alpha=1 \%$ ) dari hasil estimasi logit diatas kita dapat mengetahui variabel-variabel yang mempengaruhi secara positif terhadap pembayaran kembali pinjaman KUR usaha mikro dengan tingkat kepercayaan $99 \%$ adalah pekerjaan sampingan. Untuk nilai-p ( $\alpha=5 \%$ ) faktor-faktor yang mempengaruhi secara negatif terhadap pembayaran kembali pinjaman KUR usaha mikro adalah jenis usaha pengolahan, pengeluaran untuk makanan, sumber pinjaman lain selain KUR, tidak memakai jaminan, dan pengalihan kredit. Sedangkan yang mempengaruhi secara positif dalam pembayaran kembali pinjaman dengan tingkat kepercayaan 95\% $(\alpha=5 \%)$ adalah pengajuan kredit yang disetujui semua dari awal. Faktorfaktor yang mempengaruhi pengembalian pinjaman yang signifikan positif dengan nilai-p $(\alpha=10 \%)$ adalah pasangan bekerja dan jaminan pinjaman dengan BPKB. Sedangkan yang memberikan pengaruh negatif adalah usia. 


\begin{tabular}{|c|c|c|c|}
\hline \multicolumn{4}{|c|}{$\begin{array}{l}\text { Tabel } 7 . \\
\text { Hasil estimasi logit faktor-faktor yang mempengaruhi pembayaran kembali }\end{array}$} \\
\hline Pembayaran bagus/terlambat & Odd ratio & $\mathbf{z}$ & $P>|z|$ \\
\hline Kecamatan & 2,19 & 0,78 & 0,436 \\
\hline Gender & 0,95 & $-0,03$ & 0,976 \\
\hline Usia & 0,91 & $-1,69$ & $0,092^{*}$ \\
\hline Pendidikan_SD & 1,84 & 0,31 & 0,755 \\
\hline Pendidikan_SMP & 0,40 & $-0,43$ & 0,667 \\
\hline Pendidikan_SMA & 1,77 & 0,29 & 0,774 \\
\hline Jarak ke bank & 0,89 & $-0,94$ & 0,345 \\
\hline Jenis usaha_dagang & 7,88 & 1,23 & 0,217 \\
\hline Jenis usaha_jasa & 0,88 & $-0,10$ & 0,922 \\
\hline Jenis usaha_pengolahan & 0,60 & $-1,99$ & $0,047^{\star *}$ \\
\hline Lama usaha & 1,07 & 0,72 & 0,469 \\
\hline Hambatan usaha & 0,69 & $-0,29$ & 0,774 \\
\hline Penjualan & 1,00 & 2,39 & 0,017 \\
\hline Modal kerja & 0,99 & $-2,38$ & 0,017 \\
\hline Pengeluaran untuk makanan & 0,99 & $-2,23$ & $0,026^{* *}$ \\
\hline Pekerjaan sampingan & 49,8 & 2,60 & $0,009^{* * *}$ \\
\hline Pasangan bekerja & 4,57 & 1,60 & $0,10^{*}$ \\
\hline Sumber pinjaman lain & 0,16 & $-2,09$ & $0,03^{* *}$ \\
\hline Jumlah tanggungan anak & 1,70 & 1,10 & 0,27 \\
\hline Jaminan_tidak ada & 0,03 & $-1,99$ & $0,04^{* *}$ \\
\hline Jaminan_BPKB_motor & 5,89 & 1,67 & $0,09^{*}$ \\
\hline Pengajuan kredit tidak dibatasi & 8,36 & 2,03 & $0,04^{* *}$ \\
\hline Pengalihan kredit & 0,41 & $-1,02$ & $0,03^{* *}$ \\
\hline Periode angsuran & 0,94 & $-0,84$ & 0,40 \\
\hline Konstan & 49,1 & 0,81 & 0,41 \\
\hline
\end{tabular}

\section{Jenis Lapangan Usaha}

Jenis lapangan usaha dalam penelitian ini dikelompokkan menjadi 4, yaitu ritel/dagang, jasa, pengolahan (produksi), dan pertanian yang didalamnya termasuk peternakan dan perikanan. Jenis usaha pengolahan secara signifikan berpengaruh negatif terhadap pembayaran kembali pinjaman.

Peluang usaha pengolahan untuk tidak membayar kembali pinjaman dengan lancar sebesar 0,6 kali dibandingkan dengan jenis usaha lainnya. Dengan kata lain, jenis usaha pengolahan memiliki peluang untuk membayar terlambat sebesar 1,67 kali dibandingkan dengan jenis usaha lain. 
Jenis usaha pengolahan termasuk yang rentan dengan perubahan harga bahan bakunya. Meningkatnya bahan bakar misalnya, akan langsung meningkatkan biaya produksi tetapi usaha mikro tidak bisa serta merta langsung menaikkan harga jual produknya. Sehingga yang bisa dilakukan hanya mengurangi marjin labanya. Akibatnya usaha mikro pengolahan mengalami kesulitan dalam pembayaran kembali pinjaman. Penelitian ini sejalan dengan Roslan dan Karim (2009) yang mengungkapkan bahwa peluang gagal bayar untuk kegiatan ekonomi jasa/pendukung berkurang dibandingkan dengan kegiatan-kegiatan produksi. Faktor jenis usaha pengolahan erat kaitannya juga dengan modal kerja. Semakin tinggi biaya produksi maka semakin tinggi modal kerja yang diperlukan untuk usaha mikro. Akibatnya keuntungan perusahaan akan turun jika usaha mikro tersebut tidak mampu menaikkan penjualan.

\section{Pengeluaran Makanan}

Rumah tangga usaha mikro biasanya memiliki karakteristik proporsi pengeluaran makanan yang lebih besar dibanding dengan pengeluaran non makanan. Pada tingkat signifikasi 5\% maka variabel pengelu aran makanan dengan nilai-p 0,026 sangat signifikan negatif terhadap pembayaran kembali pinjaman lancar.

Hasil estimasi ini menunjukkan bahwa semakin tinggi pengeluaran untuk makanan maka usaha mikro, maka kesulitan untuk membayar kembali pinjaman adalah 1,01 kali lebih besar dibandingkan dengan yang proporsi pengeluaran untuk makanannya sedikit.

\section{Sumber Pinjaman}

Hasil estimasi menunjukkan bahwa keberadaan sumber pinjaman lain secara signifikan berpengaruh negatif terhadap pembayaran kembali pinjaman nasabah. Ini berarti semakin besar cicilan yang harus dibayar dari sumber-sumber pinjaman tersebut maka semakin bermasalah pembayaran kembali pinjaman.

Secara kuantitiatif, besaran parameter rasio kecenderungan untuk variabel ini adalah 0,16 kali. Ini berarti, peluang nasabah KUR yang memiliki sumber pinjaman lain untuk terlambat bayar adalah sebesar 6,25 kali dibandingkan dengan nasabah yang hanya memiliki sumber pinjaman KUR saja.

\section{Jaminan}

Dalam penelitian ini ditemukan bahwa peminjam KUR usaha mikro sangat bervariasi persyaratan jaminannya. Ada yang tanpa agunan, dengan BPKB motor, ada juga sertifikat. Hasil estimasi model menunjukkan bahwa nasabah yang tidak menggunakan jaminan atau agunan berpengaruh signifikan dalam masalah pembayaran pinjamannya. 
Peluang nasabah yang tidak menggunakan agunan untuk membayar hutang sebesar 0,033 kali dari nasabah yang menggunakan anggunan. Dengan kata lain peluang untuk terlambat membayar kembali pinjaman sebesar 30,3 kali dibandingkan dengan nasabah yang memiliki agunan. Sedangkan nasabah yang memiliki agunan BPKB motor berpengaruh secara signifikan dan memiliki peluang untuk membayar kembali pinjaman lancarnya sebesar 5,8 kali dibanding dengan yang tidak memiliki agunan. Moral hazard orang berkurang seiring dengan tidak adanya sesuatu yang merugikan dirinya atau adanya keuntungan yang diperolehnya dengan tidak membayar pinjaman dengan lancar. Namun jika ada jaminan yang dikenakan, maka usaha mikro takut jika tidak membayar pinjamannya.

\section{Pengalihan Kredit}

Pengalihan kredit usaha ke kegiatan yang bukan produktif dan menguntungkan (credit diversion) mempengaruhi pembayaran kembali pinjaman secara negatif. Usaha mikro yang menggunakan pinjaman bukan untuk hal yang produktif, maka peluang untuk gagal bayarnya sebesar 2,5 kalinya dibandingkan dengan usaha mikro yang menggunakan pinjaman buat usaha. Hasil penelitian ini sesuai dengan penelitian (Setargie, 2013) yang mengungkapkan bahwa pengalihan kredit berpengaruh secara negatif terhadap pembayaran kembali kredit karena tidak menggunakan untuk tujuan yang menguntungkan.

\section{Persetujuan Kredit Langsung}

Keputusan persetujuan kredit ini berkaitan dengan screening awal yang dilakukan oleh bank atau pihak pemberi pinjaman. Prosedur penyaringan dengan credit constrained ini dimaksudkan untuk mencegah kemungkinan terjadinya moral hazard dan untuk mengurangi risiko kredit. Bank, berdasarkan analisisnya dapat memprediksi tingkat risiko yang melekat pada pinjaman yang mereka kelola dan menghindari peminjam berisiko. Dengan memberikan semua jumlah yang diajukan berarti kepercayaan bank terhadap calon nasabah tersebut tinggi atas dasar ekpektasi pinjaman akan kembali juga besar.

Kecenderungan nasabah KUR yang kreditnya disetujui semua atau tidak mendapatkan pembatasan kredit (credit constrained) untuk membayar pinjaman dengan lancar adalah 8,3 kali dibandingkan dengan nasabah KUR yang mendapat credit constrained. Ini berarti informasi tentang nasabah bisa diperoleh oleh bank, kalau tidak biasanya bank menggunakan jaminan yang dianggap layak untuk mencegah timbulnya wan-prestasi dari nasabah.

Adanya asimetrik informasi bisa juga diatasi dengan mengenakan tingkat suku bunga yang tinggi, namun untuk program KUR tidak bisa dilakukan karena tingkat bunga sudah ditentukan oleh pemerintah. Menaikkan tingkat suku bunga pun bukan jalan terbaik karena akan meningkatkan beban usaha mikro yang akibatnya akan menyulitkan pembayaran kembali 
pinjaman. Untuk pasar kredit informal, menaikkan suku bunga sering dilakukan untuk mengatasi asimetrik informasi tersebut. Ketepatan penyaringan nasabah sangat penting agar kejadian yang diperkirakan sama dengan resiko ex-post default.Efisiensi pendekatan penyaringan bisa dilihat dari sejauh mana mampu memperkirakan dan mengamankan peminjam beresiko untuk meminimalkan gagal bayar (Ofonyelu dan Alimi, 2013).

\section{Pekerjaan Sampingan}

Pelaku usaha memiliki waktu yang fleksibel dan tergantung mereka mengaturnya. Dengan memiliki pekerjaan sampingan diharapkan akan memiliki pendapatan yang lebih besar sehingga kemampuan untuk membayar kembali pinjaman semakin besar. Peluang usaha mikro yang memiliki pekerjaan sampingan untuk membayar pinjaman KUR dengan lancar sebesar 49,8 kalinya usaha mikro yang hanya mengandalkan satu usaha saja.

Wongnaa dan Vitor (2013), dalam penelitiannya mengungkap bahwa pekerjaan tambahan dari off farm memiliki pengaruh positif dalam pembayaran hutang. Memiliki banyak usaha oleh (Tundui dan Tundui, 2012) juga mengurangi masalah dalam pembayaran pinjaman. Keuntungan dari usaha lain bisa membantu dalam pembayaran pinjaman.

\section{Pasangan Bekerja}

Rumah tangga usaha mikro yang pasangan suami/istri bekerja maka peluang untuk membayar pinjaman dengan lancar sebesar 4,5 kalinya dibanding dengan rumah tangga usaha mikro yang pasangannya tidak bekerja. Pasangan rumah tangga yang suami/istri bekerja memiliki pendapatan yang lebih besar sehingga kemampuan untuk membayar pinjaman lebih besar.

\section{Usia}

Semakin tua usia maka peluang untuk membayar pinjaman 0,9 kalinya dibanding dengan usia kepala rumah tangga yang lebih muda. Dengan kata lain, peluang rumah tangga usaha mikro yang usianya lebih muda untuk membayar pinjaman dengan lancar sebesar 1,1 kalinya dibanding dengan usaha mikro yang usia kepala rumah tangganya lebih tua.

Faktor-faktor yang berkaitan dengan karakteristik peminjam yang tidak mempengaruhi signifikan terhadap pembayaran kembali pinjaman adalah gender, dan pendidikan. Penelitian ini tidak sejalan dengan hasil Wongnaa dan Vitor (2013) dan Setargie (2013) yang melihat bahwa faktor pendidikan sangat penting mempengaruhi pembayaran kembali pinjaman. Menurutnya semakin tinggi pendidikan semakin tinggi bisa berefisiensi dan lebih produktif. Sedangkan faktor gender, Roslan dan Karim (2009) mengatakan bahwa gender berpengaruh positif terhadap pembayaran kembali pinjaman atau dengan kata lain kegagalan pria untuk 
membayar pinjaman lebih besar dibandingkan dengan wanita (wongnaa dan Vitor, 2013). Gender menurut hasil penelitian Setargie (2013), tidak signifikan tetapi bertanda negatif yang mengindikasikan bahwa peminjam perempuan adalah pembayar kredit yang lebih baik dari laki-laki. Dalam penelitian ini, sejalan dengan Setargie (2013), meskipun gender tidak signifikan mempengaruhi rumah tangga usaha mikro untuk membayar pinjaman, namun memiliki arah koefisien negatif yang berarti wanita mmenunjukkan peluang untuk membayar pinjaman lebih baik dibanding dengan pria.

\section{Lokasi Usaha}

Lokasi dimana rumah tangga usaha mikro berada ternyata tidak signifikan mempengaruhi dalam membayar pinjaman. Lokasi tidak mempengaruhi signifikan dalam pembayaran KUR karena karakteristik dari usaha mikro bersifat homogen dan penyaluran maupun persyaratan KUR sama di setiap kecamatan di Indonesia. Kecamatan Margorejo sebagai kecamatan yang lebih mendekati perkotaan, sedangkan Kecamatan Dukuhseti lebih bersifat perdesaan dan pesisir yang sangat jauh dari perkotaan. Namun demikian, karakterisitik dalam membayar kembali pinjaman KUR baik sebagai orang pedesaan maupun perkotaan tidak signifikan mempengaruhi.

Masyarakat pedesaan yang dianggap memiliki keterkaitan dan keterikatan sosial dan budaya yang lebih tinggi dibandingkan dengan masyarakat perkotaan, ternyata tidak memiliki perbedaan yang signifikan dalam hal kecendrerungan mempengaruhi pembayaran kembali KUR. Namun demikian, meski tidak signifikan, koefisien Dukuhseti memiliki arah yang positif.

Spesifikasi model dalam paper ini berbeda dengan penelitian Srinivas (2015) yang memasukan faktor-faktor sosial budaya seperti tempat asal peminjam, bahasa daerah yang digunakan dan agama. Dalam penelitiannya Srinivas menemukan faktor-faktor tersebut berperan penting dalam pembayaran kembali pinjaman informal. Namun demikian, pinjaman formal dan pinjaman informal tidak bisa disandingkan karena pnjaman informal sangat menggantungkan pada tingkat kepercayaan kedua pihak, sedangkan pinjaman formal sangat menekankan pada nilai ekonomi jaminan.

\section{Jumlah Tanggungan}

Semakin besar tanggungan keluarga maka semakin besar pengeluaran untuk makanan. Hasil estimasi menunjukkan jumlah tanggungan tidak signifikan mempengaruhi kecenderugan usaha mikro untuk tidak membayar pinjaman. Hal ini tidak sejalan dengan penelitian Setargie (2013), dimana jumlah tanggungan signifikan secara negatif terhadap pembayaran pinjaman.

Dalam penelitian ini, lebih dari 75 persen nasabah memiliki anak kurang dari tiga. Jumlah tanggungan yang diukur dalam penelitian ini hanya jumlah anak yang masih menjadi tanggungan orang tua. Hasil estimasi kemungkinan berbeda ketika pengukuran variabel beban 
tanggungan mencakup semua orang yang menjadi tanggungan suatu keluarga, termasuk orang tua, pasangan yang tidak bekerja, ponakan, dan lainnya.

\section{Karakteristik Usaha dan Periode Pembayaran}

Untuk karakteristik usaha, faktor-faktor yang tidak signifikan mempengaruhi pembayaran kembali pinjaman adalah faktor lama usaha. Lama usaha bisa diasumsikan dengan pengalaman. Ini berarti tidak sejalan dengan penelitian Wongnaa dan Vitor (2013) dan Tundui (2013) dimana pengalaman, memiliki hubungan yang signifikan positif dalam pembayaran kembali pinjaman.

Periode pembayaran tidak berpengaruh signifikan terhadap kecenderungan nasabah untuk membayar kembali pinjamannya, meski arahnya menunjukkan negatif. Hasil estimasi ini berbeda dengan penelitian Vitor (2012) yang menemukan periode pembayaran signifikan negatif mempengaruhi pembayaran kembali.

\section{KESIMPULAN}

Studi empiris dalam paper ini telah menunjukkan faktor-faktor yang mempengaruhi signifikan pembayaran pinjaman KUR oleh rumah tangga usaha, mencakup faktor usia, jenis usaha, pengeluaran makanan, pekerjaan sampingan, pasangan bekerja, memiliki sumber pinjaman lain selain KUR, jaminan, screening awal (tidak mendapat pembatasan kredit) dan pengalihan kredit.

Secara umum, faktor-faktor karakteristik peminjam seperti gender (wanita), peningkatan usia, pendidikan yang lebih tinggi maupun lokasi pedesaan dianggap sebagai representatif dari faktor moral hazard yang lebih baik dalam pembayaran pinjaman. Nmun kenyataannya tidak signifikan mempengaruhi dalam pembayaran pinjaman. Sehingga berkaitan dengan utang piutang, faktor moral hazard tidak mampu diandalkan untuk menilai seseorang jujur atau tepat waktu dalam pembayaran pinjaman KUR. Faktor objektif seperti jenis usaha dan jaminan yang lebih signifikan mempengaruhi pembayaran pinjaman KUR.

Perlu digarisbawahi bahwa penelitian empiris yang dituangkan dalam paper ini, memiliki keterbatasan dalam jumlah sampel, dan terbatas hanya dari satu kabupaten yang sama. Dengan demikian, paper ini perlu untuk dikembangkan dengan memperluas data dan cakupan wilayah secara nasional. 


\section{DAFTAR PUSTAKA}

Armendariz, B. dan Morduch, J. (2005). The Economics of Microfinance, MIT Press, Cambridge, MA.

Chakravarty, S., Iqbal, S.M.Z., Shahriar, A.Z.M. (2013). Are Women "Naturally" Better Credit Risks in Microcredit? Evidence from Field Experiments in Patriarchal and Matrilineal Societies in Bangladesh. Annual Meeting of the American Economic Association in Philadelphia.

D'espallier, B. Guerin, I. Mersland, R. (2011). Woman and Repayment in Microfinance: A Global Analysis. World Development Vol. 39, No. 5. Pp 758-772.

Gebeyehu, Z. Beshire, H. And Haji, J. (2013). Determinants of Loan Repayment Performance of Smallholder Farmers: The Case of Kalu District, South Wollo Zone, Amhara National Regional State, Ethiopia. International Journal of Economics, Business and Finance Vol. 1, No. 11, December 2013, PP: 431-446, ISSN: 2327-8188 (Online) Available online at http://ijebf.com/

Godquin, M. (2004). Micro Finance Repayment Performance in Bangladesh: How to Improve the Allocation of Loan by MFls. World Development, Vol. 32, No. 11, pp. 1909-1926

Ibeleme, Sylvester N.O., Godwin C. O., and Odionye, J. C. (2013). Determinants of loan size and repayment performance of small oil producers in Nigeria: The case study of Abia State. International Journal of Business Management and Administration Vol. 2(3), pp. 043-054

Jalaludin. (2002). Studi Komparasi Kinerja Bank Perkreditan Rakyat (BPR) yang Berdasarkan Syariah dengan BPR Konvensional dalam Pemberian kredit untuk Pengusaha Kecil Perdesaan di Nusa Tenggara Barat (NTB). Tidak dipublikasikan. Program Pasca Sarjana IPB. Bogor

Juanda, B. (2009). Ekonometrika Pemodelan dan Pendugaan. Bogor: IPB Press.

Lukman, S. dkk. (2008). Kajian Upaya Peran Microbanking dan Pendekatan Pembiayaan Kelompok dalam Rangka Pengembangan UMK di Sumatra Barat. Bank Indonesia dan Centre for Banking Reasearch Universitas Andalas

Mokhtar, S.H., Nartea, G., and Gan, C. (2012). Determinants of microcredit loans repayment problem among microfinance borrowers in Malaysia. International Journal of Business and Social Research (IJBSR), Vol. 2, No. 7, December 2012

Nawai, N., Shariff, M.N. (2013). Determinants of Repayment Performance in Microfinance Programs in Malaysia. Labuan Bulletin of International Business \& Finance, Vol. 11, 2013, $14-29$. 
Ofonyelu, C., and Alimi, R.S. (2013). Perceived Loan Risk and Ex Post Default Outcome: Are the Bank's Loan Screening Criteria Efficient?. Asian Economic and Financial Review, 2013, 3(8):991-1002

Ojiako, I. A, and Ogbukwa, B. C. (2012). Economic Analysis of Loan Repayment Capacity of Smallholder Cooperative Farmers in Yewa North Local Government Area of Ogun State, Nigeria. African Journal of Agricultural Research Vol. 7(13), pp. 2051-2062.

Oke, J.T.O., Adeyemo, R., and Agbonlahor, M.U. (2007). An Empirical Analysis of Microcredit Repayment in Southwestern Nigeria. Humanity \& Social Sciences Journal 2 (1): 63-74, ISSN $1818-4960$

Okojie, C., Monye-Emina, A., Eghafona, K., Osaghae, G., and Ehiakhamen, J.O. (2010). Institutional Environment and Access to Microfinance by Self-employed Women in the Rural Areas of Edo State. International Food Policy Research Institute. IFPRI. Brief No.14

Onyeagocha, S.U.O, Chidebelu, S. A. N. D, Okorji, E.C.O, Ukoha, A.H. Osuji, M.N and Korie, O.C. (2012). Determinants of Loan Repayment of Microfinance Institutions in Southeast States of Nigeria. International Journal of Social Science and Humanities Vol.1 No.1 April 2012 ISSN 2166-7721

Roslan, A.H. and Karim, M.Z.A. (2009). Determinants of Microcredit Repayment in Malaysia: The Case of Agrobank. Humanity \& Social Science Journal 4(1): 45-52, 2009

Srinivas, H. (2015). Borrower Evaluation in the Informal Credit Markets. GDRC Reseaarch Output E-110. Kobe, Japan: Global Development Research Center. Retrieved from http://www.gdrc. org/icm/b-eval.html on Thursday, 31 December 2015

Supadi dan Sumedi. (2004). Tinjauan Umum Kebijakan Kredit Pertanian. ICASERD working paper No. 25. Pusat Penelitian dan Pengembangan Sosial Ekonomi Pertanian, Departemen Pertanian

Voice of Indonesia. (2012). Kredi Usaha Tani Macet. . http://www.id.voi.co.id/voi-komentar/1853kredit-usaha-tani-macet

Setargie, S. 2013. Credit Default Risk and its Determinants of Microfinance Industry in Ethiopia. The Journal of Young Economists. http://joyeconomists.com/2014/07/19/setargie-2013credit-default-risk-and-microfinance-in-ethiopia/ 
Tundui, C., and Tundui, H. (2012). Microcredit, Micro Enterprising and Repayment Myth: The Case of Micro and Small Women Business Entrepreneurs in Tanzania. American Journal of Business and Management Vol. 2, No. 1, 2013, 20-30

Vitor, D.A. (2012). Determinants of Loan Repayment Default among Farmers in Ghana. Journal of Development and Agricultural Economics Vol. 4(13), pp. 339-345, November 2012. Available online at http://www.academicjournals.org/JDAE

Wongnaa, C.A., and Vitor, D.A. (2013). Factors Affecting Loan Repayment Performance Among Yam Farmers in the Sene District, Ghana. Agris on-line Papers in Economics and Informatics. Volume V Number 2, 2013 
Halaman ini sengaja dikosongkan 